\title{
DEVELOPMENT OF THE ACADEMICS' E-READINESS QUESTIONNAIRE (ARQ) FOR MEDICAL UNIVERSITIES
}

\author{
Dr. Nahid ZARIFSANAIEY \\ ORCID: 0000-0002-1297-8271 \\ Department of e-Learning \\ Shiraz University of Medical Sciences \\ Shiraz, Iran \\ Seyede Shima KARANJAM \\ ORCID: 0000-0003-3736-5073 \\ Faculty of Management \\ University of Tehran \\ Tehran, Iran \\ Dr. Mohammad Hossein KAVEH \\ ORCID: 0000-0002-9141-3243 \\ Department of Health Promotion, Faculty of Public Health \\ Shiraz University of Medical Sciences \\ Shiraz, Iran \\ Dr. Manoosh MEHRABI \\ ORCID: 0000-0002-2024-9415 \\ Department of e-Learning in Medical Sciences \\ Shiraz University of Medical Sciences \\ Shiraz, Iran
}

Received : 29/04/2018 Accepted: 24/07/2018

\section{ABSTRACT}

The present study is conducted to implement the newly developed questionnaire to assess readiness of academics for Implementation of e-learning programs. The questionnaire was developed and its validity, and reliability was evaluated. Then a cross sectional study was conducted including 907 academics in three categories (faculties, students, and employees) of Shiraz University of Medical Sciences. Data were analyzed in SPSS-16 using descriptive and inferential statistics. The results of the implementation of the questionnaire showed a significant relationship between e-learning knowledge and participants' position in the university, as the professors and students had higher levels of this knowledge compared to the university employees $(\mathrm{P}<0.001)$. There was a significant relationship between e-learning knowledge and academic degree in the study subjects $(\mathrm{P}=0.004)$. Skills and attitude were also significantly related to the variables of position, academic degree, and place of residence and hours of internet use. Skills, knowledge and attitude were all related to computer and internet access and language used on the internet.

Keywords: Applications in subject areas, distance education, telelearning.

\section{INTRODUCTION}

e-Learning is a new approach which has crossed traditional education and has created flexible access to learning (Zarshenas, Keshavarz, Momennasab, \& Zarifsanaiey, 2017), and is defined as using electronic tools in designing, presenting and implementing of an educational environment to reach a sustainable 
learning level(Karanjam, Karanjam, \& Sanaiey, 2017). Sustainable learning is a key point in the educational area which improve students' achievements through self-directed learning (Saeid \& Mehrabi, 2013).

It is obvious that in the era of rapid technological changes, e-Learning can play an important role in educational development and overcome many educational problems in the society, such as: growing need of education, lack of fair access to content and educational centers, lack of certified teachers tailored to students' need, and high cost of training and educational services. So it is necessary that e-Learning providers be ready for creating desirable conditions and determine the amount of readiness. This determination makes the policy makers design and implement their future programs based on present level of readiness (Aslani, Babakhani, Karami, \& Amirteimori, 2016). In Iran it is predicted that e-learning programs will grow quickly and that the student acceptance rate will reach to 10000 student per university (Darab \& Montazer, 2011).

e-Readiness has many definitions but the definition accepted in the present study is "The capabilities of the organization together with and the capabilities of the educational authorities (stakeholders, key-persons, faculty members and the students) for effective and efficient application of the electronic media"(Machado, 2007).

A number of well-known micro and macro e-readiness assessment tools and models have been proposed to date. Macro e-readiness indicators are often assessed by reputable international institutions to compare and rank countries while micro e-readiness compares more minor indicators such as Networking, Application, Web Accessibility and Readiness (known as NAWAR) and educational and non-educational companies and organizations in one or several countries (Hourali, Fathian, Montazeri, \& Hourali, 2013). Researchers have presented various indicators for the assessment of readiness at the micro level (which is the objective of the present study) according to the organizational circumstances of their given studies. Before presenting the indicators identified in the present study, a number of indicators presented in previous studies are briefly reviewed. In one study, Keramati et al. used three groups of indicators to assess e-readiness, including technical, organizational and social indicators (Keramati, Afshari-Mofrad, \& Kamrani, 2011).

In another study, Abo-el-maged assessed e-readiness according to the subjects' optimism, innovation, sense of difficulty and insecurity (Aboelmaged, 2014). In another study, Ahmed assessed e-readiness using four indicators, including IT infrastructures for e-learning, learner's acceptance and use of integrated learning, technical and organizational support and instructor's characteristics (Ahmed, 2010). In another study, Akaslanand Law proposed ten indicators for assessing e-readiness, including personal skills, technology, organizational features, content, perceived simplicity, perceived benefits, instructors' training, learners' learning, personal characteristics and facilities (Akaslan \& Law, 2011). Aydin and Tasci used a model with the eight factors of financial readiness, technical skills and talent, content readiness, facilities, human resources, environmental conditions and sociological and psychological conditions to assess e-readiness at the micro level (Aydın \& Tasci, 2005). In one last study, Tarhini et al. performed an extensive study and proposed four indicators for assessing e-readiness in educational organizations, including perceived simplicity, perceived benefits, subjective norms and quality of work life (Tarhini, Hone, \& Liu, 2014).

Extensive review of previous studies shows that each e-readiness model is focused on one criterion more than others. The present study based on virtual university reference model (VURM), focus on Academic's readiness and its goal is the development, validation and implementation of the Academics' E-Readiness questionnaire (ARQ) at Shiraz University of Medical Sciences to propose for other medical universities. 


\section{METHODOLOGY}

The present study is an applied research in objectives and a descriptive, cross-sectional study in terms of data collection that seeks to develop, validate and implement an e-readiness assessment questionnaire aimed at professors, employees and students at Shiraz University of Medical Sciences.

The initial questionnaire was developed according to a review of previous references, studies and tools. First, following an extensive library study and a search for keywords including 'e-learning', 'e-readiness' and 'information and communication technology' in databases such as ISI, Pubmed, Scopus and Google Scholar, relevant research literature and theoretical principles were identified and compiled. The initial questionnaire developed in this study consisted of five parts: 1) eight items that obtained participants' demographic information, 2) six items that dealt with computer and internet access, 3) twelve items on computer skills, 4) ten items on e-learning knowledge and 5) ten items for assessing the attitude toward elearning. A three-point Likert scale for the knowledge and skills parts and a five-point Likert scale for the attitude part were used. To report the result, The face and content validity of the questionnaire were assessed using the views expressed by five e-learning professors and experts about the content, form and general composition of the items.

\section{Participants}

To check the readiness of e-learning among academic's based on their own perception, the questionnaire was given to 907 subjects and the results obtained were analyzed. Our sampling frame consisted of all professors, employees and students of the seven schools of Shiraz University of Medical Sciences. A random sample was selected from the sampling frame by stratified random sampling method. This sampling method was used to include all stratum from all departments of all schools. The study inclusion criteria were studying, teaching or working in one of the schools of Shiraz University of Medical Sciences and their acceptance to participate in the study. Given these criteria, 907 subjects (600 students, 200 professors and 107 employees) were selected as the study samples.

\section{Data Collection and Analysis}

Data were collected by visiting seven schools of Shiraz University of Medical Sciences after ensuring compliance with research ethics and obtaining letters of introduction. The samples required were separately selected from each school according to a table of random numbers. All participants read and signed the informed consent form. The code of local ethics committee was EC-88-4618. Data was analysed using SPSS software v.16. Quantitative variables were assessed by means and standard deviation. Their differences were evaluated by student $\mathrm{t}$-test and one way ANOVA. The qualitative variables were demonstrated by frequency and percent. Their differences were evaluated by chi-square test. P-value below 0.05 was considered statistically significant.

\section{The Scale}

Construct validity was assessed by an exploratory factor analysis using the analysis of the main components and the varimax rotation. The reliability of the questionnaire was assessed by measuring the internal consistency of the various parts of the questionnaire using Cronbach's alpha coefficient. The split-half reliability was also assessed using the Kuder-Richardson Formula 20 or KR-20. Overall score correlation coefficient for test-retest reliability in a 30 days follow up was assessed. 


\section{FINDINGS}

\section{Validity of the ARQ}

Following the initial design of the questionnaire and the confirmation of its face validity, its construct validity was also assessed by an exploratory factor analysis using the analysis of the main components and the varimax rotation $(\mathrm{KMO}=0.869)$.

\section{Reliability of the ARQ}

The reliability of the questionnaire was determined by measuring the internal consistency of the various parts of the questionnaire using Cronbach's alpha coefficient (0.738). Overall score correlation coefficient for test-retest reliability was 0.87 . The split-half reliability of the questionnaire was also assessed using the Kuder-Richardson Formula 20 (KR-20) (0.81).

\section{Implementation of the ARQ at Shiraz University of Medical Sciences}

This questionnaire was implemented for 907 subjects (600 students, 200 professors and 107 employees) at Shiraz University of Medical Sciences.

Tables 1 to 3 present the results obtained from comparison of knowledge, skill and attitude based on position, gender, age, marital status, academic degree, type of school and place of residency of participants. We found no significant relationships between knowledge, skill and attitude and socio-demographic variables including age, gender, marital status, place of residence and school of employment (or education). The questionnaire has three different parts which filled based on self report of participants. The knowledge part has three different options: "True", "False", "I don't know". We used "Favorable" for "True" and "Unfavorable" for both "False" and "I don't know". The Skill part was contained of: "Not skilled", "Skilled to some extent", "Skilled". We used "Favorable" for "Skilled" and "Skilled to some extent" and "Unfavorable" for "Not Skilled". The Attitued part has 5 options: "Strongly Agree", "Agree", "I don't have any idea", "Disagree", "Strongly Disagree". We used "favorable" for the firs two one and "Unfavorable" for the rest of them. Findings are shown in below tables:

Table 1.The e-learning knowledge of the study samples by demographic, employment and education details

\begin{tabular}{|c|c|c|c|c|c|}
\hline \multirow{2}{*}{$\begin{array}{l}\text { Demographic } \\
\text { Variables }\end{array}$} & & \multicolumn{2}{|c|}{ Knowledge Level } & \multirow{2}{*}{$\begin{array}{l}\text { Statistical } \\
\text { Test }\end{array}$} & \multirow[t]{2}{*}{ P-Value } \\
\hline & & Unfavorable & Favorable & & \\
\hline \multirow{3}{*}{ Position } & Professor & $24(40.0 \%)$ & $37(60.0 \%)$ & \multirow{3}{*}{ Chi-Square } & \multirow[t]{3}{*}{$<0.001$} \\
\hline & Employee & $71(66.7 \%)$ & $36(33.3 \%)$ & & \\
\hline & Student & $150(25.0 \%)$ & $450(75.0 \%)$ & & \\
\hline \multirow[t]{2}{*}{ Gender } & Female & $181(48.9 \%)$ & $189(51.1 \%)$ & \multirow[t]{2}{*}{ Chi-Square } & \multirow[t]{2}{*}{.392} \\
\hline & Male & $101(43.9 \%)$ & $129(56.1 \%)$ & & \\
\hline $\begin{array}{l}\text { Age) Mean } \pm \\
\text { SD) }\end{array}$ & & $23.61(5.686)$ & $24.46(6.342)$ & $\begin{array}{l}\text { two sample t- } \\
\text { test }\end{array}$ & 0.05 \\
\hline
\end{tabular}

\begin{tabular}{llllll}
\hline Marital & Married & $90(41.7 \%)$ & $120(58.3 \%)$ & Chi-Square & .269 \\
\cline { 2 - 4 } Status & Single & $258(46.5 \%)$ & $294(53.5 \%)$ & & \\
\cline { 2 - 4 } & Widowed & or & $0(.0 \%)$ & $1(100.0 \%)$ & \\
\cline { 1 - 2 } $\begin{array}{l}\text { Academic } \\
\text { Degree }\end{array}$ & $\begin{array}{l}\text { Divorced } \\
\text { Bachelor's }\end{array}$ & $125(44.4 \%)$ & $147(54.3 \%)$ & Chi-Square & .004 \\
\hline
\end{tabular}




\begin{tabular}{|c|c|c|c|c|c|}
\hline & Master's or & $200(46.5 \%)$ & $230(53.5 \%)$ & & \\
\hline & Doctoral Degree & & & & \\
\hline & Subspecialty & $19(31.8 \%)$ & $42(68.2 \%)$ & & \\
\hline & Degreeand & & & & \\
\hline & Above & & & & \\
\hline School & Medicine & $66(40.2 \%)$ & $86(59.8 \%)$ & Chi-Square & .412 \\
\hline & Dentistry & $66(53.9 \%)$ & $57(46.1 \%)$ & & \\
\hline & Paramedicine & $31(49.2 \%)$ & $32(50.8 \%)$ & & \\
\hline & Management & $25(45.0 \%)$ & $32(55.0 \%)$ & & \\
\hline & Nursing & $25(36.8 \%)$ & $43(63.2 \%)$ & & \\
\hline & Pharmacy & $51(47.7 \%)$ & $56(52.3 \%)$ & & \\
\hline & Health & $44(45.8 \%)$ & $52(54.2 \%)$ & & \\
\hline & Kish Branch & $48(49.5 \%)$ & $49(50.5 \%$ & & \\
\hline Place of & Fars Province & $233(45.3 \%)$ & $279(54.7 \%)$ & Chi-Square & .493 \\
\hline Residence & $\begin{array}{l}\text { Out of Fars } \\
\text { Province }\end{array}$ & $118(45.7 \%)$ & $138(54.3 \%)$ & & \\
\hline
\end{tabular}

According to the results of table 1 , there is a significant relationship between the level of e-learning knowledge and employment status in the study subjects, and a higher level of knowledge was observed in the professors and students in comparison with employees $(\mathrm{P}<0.001)$. A significant relationship was also observed between knowledge and academic degree in the subjects, so that the subjects with a doctoral degree and above had higher levels of knowledge than the others $(\mathrm{P}=0.004)$.

Table 2. The computer skills of the study samples by demographic, employment and education details

\begin{tabular}{|c|c|c|c|c|c|}
\hline \multirow{2}{*}{\multicolumn{2}{|c|}{ Demographic Variable }} & \multicolumn{2}{|c|}{ Skills } & \multirow{2}{*}{$\begin{array}{l}\text { Statistical } \\
\text { Test }\end{array}$} & \multirow[t]{2}{*}{ P-Value } \\
\hline & & Unfavorable & Favorable & & \\
\hline \multirow[t]{3}{*}{ Position } & Professor & $18(29.5 \%)$ & $43(70.5 \%)$ & \multirow[t]{3}{*}{ Chi-Square } & \multirow[t]{3}{*}{.026} \\
\hline & Employee & $34(31.6 \%)$ & $73(67.4 \%)$ & & \\
\hline & Student & $256(42.6 \%)$ & $344(57.4 \%)$ & & \\
\hline \multirow[t]{2}{*}{ Gender } & Female & $239(64.6 \%)$ & $131(59.5 \%)$ & \multirow[t]{2}{*}{ Chi-Square } & \multirow[t]{2}{*}{.101} \\
\hline & Male & $80(35.4 \%)$ & $150(40.5 \%)$ & & \\
\hline \multicolumn{2}{|l|}{ Age } & $\begin{array}{l}\text { Mean } \pm \text { SD } \\
23.58(5.581)\end{array}$ & $\begin{array}{l}\text { Mean } \pm \text { SD } \\
24.43(6.369)\end{array}$ & $\begin{array}{l}\text { Independent t- } \\
\text { test }\end{array}$ & .054 \\
\hline \multirow{3}{*}{$\begin{array}{l}\text { Marital } \\
\text { Status }\end{array}$} & Married & $89(42.6 \%)$ & $121(57.4 \%)$ & \multirow[t]{3}{*}{ Chi-Square } & \multirow[t]{3}{*}{.162} \\
\hline & Single & $210(38.0 \%)$ & $342(62.0 \%)$ & & \\
\hline & $\begin{array}{l}\text { Widowed or } \\
\text { Divorced }\end{array}$ & $1(100.0 \%)$ & $0(0.0 \%)$ & & \\
\hline \multirow{5}{*}{$\begin{array}{l}\text { Academic } \\
\text { Degree }\end{array}$} & Bachelor's & $137(50.5 \%)$ & $135(49.4 \%)$ & \multirow[t]{5}{*}{ Chi-Square } & \multirow[t]{5}{*}{.0001} \\
\hline & DegreeandBelow & & & & \\
\hline & Master's or & $176(41 \%)$ & $254(59 \%)$ & & \\
\hline & Doctoral Degree & & & & \\
\hline & $\begin{array}{l}\text { Subspecialty } \\
\text { Degreeand } \\
\text { Above }\end{array}$ & $15(25.0 \%)$ & $46(75.0 \%)$ & & \\
\hline \multirow[t]{2}{*}{ School } & Medicine & $68(44.8 \%)$ & $84(55.2 \%)$ & \multirow[t]{2}{*}{ Chi-Square } & \multirow[t]{2}{*}{$<0.001$} \\
\hline & Dentistry & $45(36.5 \%)$ & $78(63.5 \%)$ & & \\
\hline
\end{tabular}




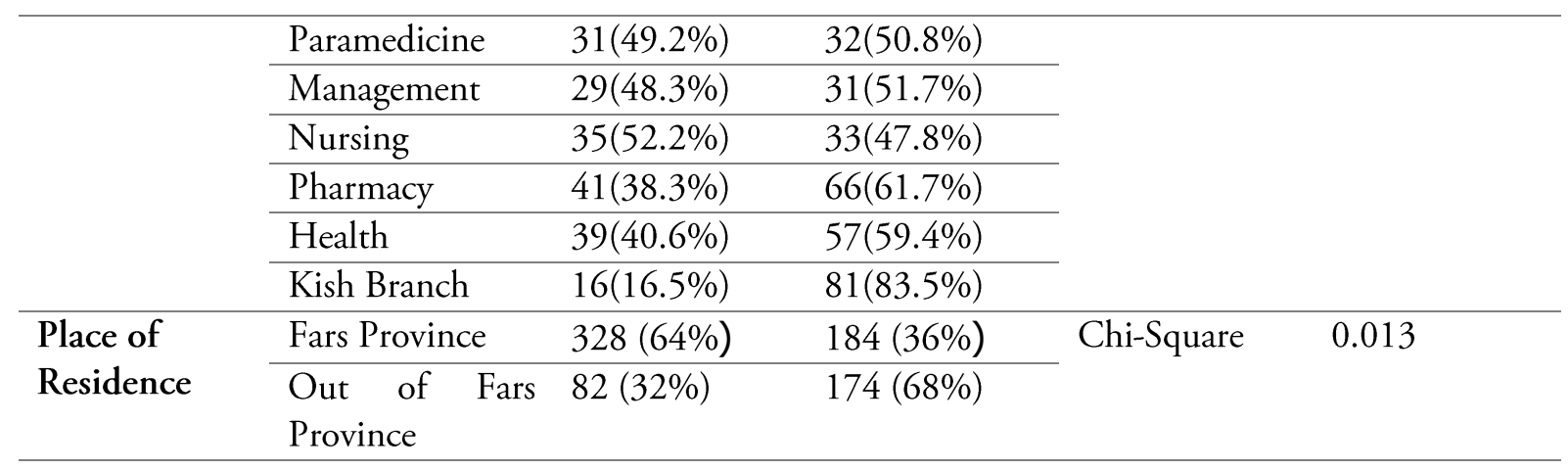

The level of computer skills was determined in the subjects by their demographic, employment and education details in Table 2 .

The results indicate that there is a significant relationship between position in the university and computer skills, so that the professors had better computer skills compared to the other subjects $(\mathrm{P}=0.026)$. A significant relationship was also observed between participants' computer skills and academic degree, so that those with higher academic degrees had better computer skills, and those with a doctoral degree and above were more skilled than the others $(\mathrm{P}<0.001)$.

The results also showed a significant relationship between participants' computer skills and school of employment (or education), so that the teachers, students and employees of the Kish Branch of the university had better computer skills than those in the other schools $(\mathrm{P}<0.001)$. Moreover, the participants who resided in Fars province were more skilled than those living out of this province $(\mathrm{P}=0.013)$.

Participants' attitude toward e-learning was also assessed by their demographic, employment and education details. Table 3 presents the results of the analysis of these details.

Table 3. Attitude toward e-learning of the study samples by demographic, employment and education details

\begin{tabular}{|c|c|c|c|c|c|}
\hline \multirow{2}{*}{\multicolumn{2}{|c|}{ Demographic Variable }} & \multicolumn{2}{|c|}{ Attitude } & \multirow{2}{*}{$\begin{array}{l}\text { Statistical } \\
\text { Test }\end{array}$} & \multirow[t]{2}{*}{ P-Value } \\
\hline & & Unfavorable & Favorable & & \\
\hline \multirow[t]{3}{*}{ Position } & Professor & $2(2.9 \%)$ & $59(97.1 \%)$ & \multirow[t]{3}{*}{ Chi-Square } & \multirow[t]{3}{*}{.001} \\
\hline & Employee & $19(17.9 \%)$ & $88(82.1 \%)$ & & \\
\hline & Student & $70(11.6 \%)$ & $530(88.4 \%)$ & & \\
\hline \multirow[t]{2}{*}{ Gender } & Female & $181(49.1 \%)$ & $189(50.9 \%)$ & \multirow[t]{2}{*}{ Chi-Square } & \multirow[t]{2}{*}{0.42} \\
\hline & Male & $105(46.0 \%)$ & $125(54.0 \%)$ & & \\
\hline \multicolumn{2}{|l|}{ Age } & $\begin{array}{l}\text { Mean } \pm \text { SD } \\
23.58(5.581)\end{array}$ & $\begin{array}{l}\text { Mean } \pm \text { SD } \\
24.43(6.369)\end{array}$ & $\begin{array}{l}\text { Independent t- } \\
\text { test }\end{array}$ & .054 \\
\hline \multirow{3}{*}{$\begin{array}{l}\text { Marital } \\
\text { Status }\end{array}$} & Married & $84(40 \%)$ & $126(60 \%)$ & \multirow[t]{3}{*}{ Chi-Square } & \multirow[t]{3}{*}{.162} \\
\hline & Single & $215(39.0 \%)$ & $337(61.0 \%)$ & & \\
\hline & $\begin{array}{l}\text { Widowed or } \\
\text { Divorced }\end{array}$ & $1(100.0 \%)$ & $0(0.0 \%)$ & & \\
\hline \multirow{4}{*}{$\begin{array}{l}\text { Academic } \\
\text { Degree }\end{array}$} & Bachelor's & $158(58 \%)$ & $114(42 \%)$ & \multirow[t]{4}{*}{ Chi-Square } & \multirow[t]{4}{*}{.0001} \\
\hline & DegreeandBelow & & & & \\
\hline & $\begin{array}{l}\text { Master's or } \\
\text { Doctoral Degree }\end{array}$ & $133(31 \%)$ & $297(69 \%)$ & & \\
\hline & $\begin{array}{l}\text { Subspecialty } \\
\text { Degreeand Above }\end{array}$ & $12(20.0 \%)$ & $49(80.0 \%)$ & & \\
\hline School & Medicine & $63(41.4 \%)$ & $89(58.6 \%)$ & Chi-Square & $<0.001$ \\
\hline
\end{tabular}




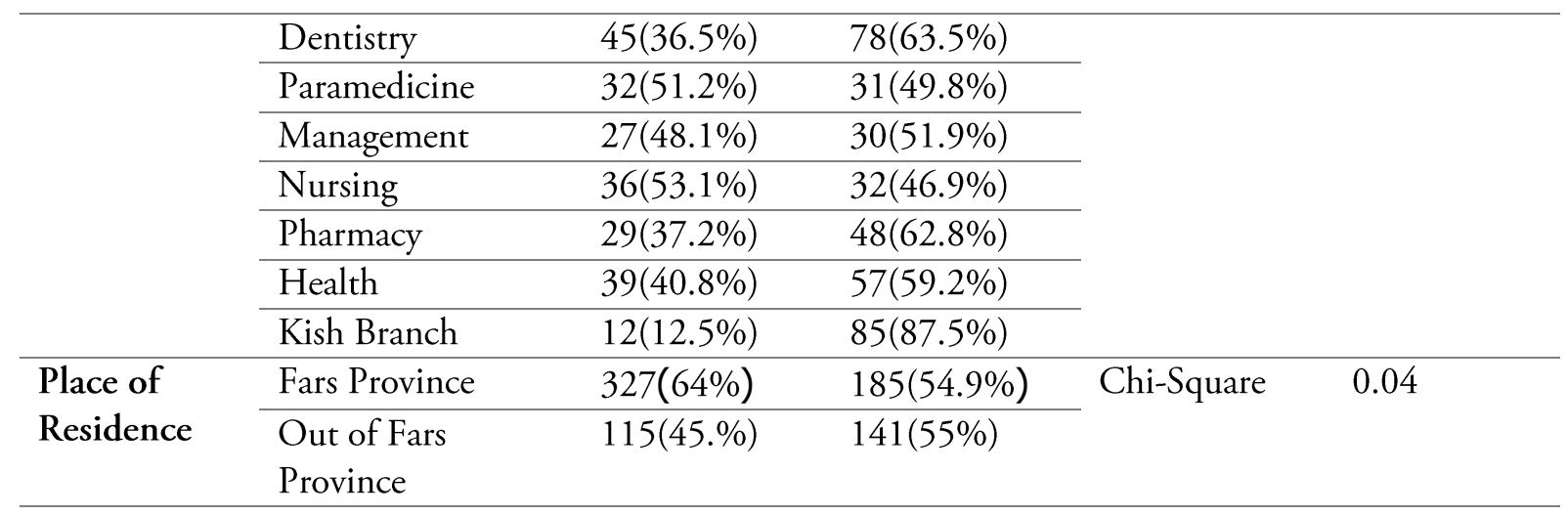

Table 3 showed a significant relationship between participants' attitude toward e-learning and their position, so that the professors had a better attitude compared to the other subjects $(\mathrm{P}=0.001)$. A significant relationship was also observed between participants' attitude toward e-learning and academic degree, so that their attitude improved as they achieved higher levels of education, and those with a doctoral degree and above had a better attitude toward e-learning compared to the others $(\mathrm{P}<0.001)$. There was also a significant relationship between the attitude toward e-learning and the school of employment (or education), so that the teachers, students and employees of the Kish Branch of the university had better attitudes compared to those in the other schools $(\mathrm{P}<0.001)$. Moreover, participants living in Fars province showed better attitudes compared to those living out of this province $(\mathrm{P}=0.04)$.

\section{DISCUSSIONS and CONCLUSION}

The present study was conducted to develop and validate a questionnaire for assessing academics' e-learning readiness at Shiraz University of Medical Sciences. The present quantitative tool development study is an applied research in objectives and a simple, descriptive, cross-sectional survey in terms of data collection. Relevant research literature and theoretical principles were identified through an extensive library study and a search of databases. The questionnaire was designed and validated and field data were then collected and analyzed. The field study population consisted of all the professors, employees and students of the seven schools of Shiraz University of Medical Sciences from 2011 to 2014, 907 of whom (600 students, 200 professors and 107 employees) were ultimately selected for the study through stratified random sampling. The questionnaire developed is a researcher-made questionnaire with five parts that contain items on demographic information (eight items), computer and internet access (six items), computer skills (12 items), e-learning knowledge (ten items) and attitude toward e-learning (ten items).The face validity of the questionnaire was confirmed by e-learning professors and experts, and its construct validity was assessed and confirmed using the varimax rotation $(\mathrm{KMO}=0.869)$ and its reliability was confirmed with a Cronbach's alpha coefficient of 73.8. Overall score correlation coefficient for test-retest reliability was 0.87 . The splithalf reliability of the questionnaire was also assessed using the Kuder-Richardson Formula 20 (KR-20).

Data were analyzed in SPSS-16 using descriptive and inferential statistics, including the Chi-square test and the independent t-test. The results obtained are presented in three parts, including knowledge, computer skills, and attitude toward e-learning.

The results of some studies conducted on this subject have been consistent with the present findings; for instance, in one study, Emami explored the key factors of a successful e-learning and examined the readiness of departments in the school of medicine and concluded that there are no significant relationships between the key factors of success in this field and the variables of age and gender (Emami, 2010). In another study, Vahidi reviewed e-readiness assessment models and developed a new model for the deployment of a mobile 
e-learning system and then assessed the e-readiness of the E-Learning Center of Isfahan University of Technology. The results obtained showed that this center does not currently have the e-readiness required for deploying a mobile e-learning system. Moreover, no significant relationships were observed between participants' position and their commitment to and interest in the deployment of a mobile e-learning systems (Vahidi, 2013). Some researchers have also examined e-readiness in several companies or at the larger scale of whole industries. For example, MultaandBrakel examined the e-readiness of Small and Medium Enterprises (SME) in communication and IT in Botswana and found that the country was not ready for e-learning (Mutula \& van Brakel, 2006). Another important point to consider with regard to the studies conducted on e-readiness concerns the factors, components, dimensions, indicators and variables used to assess, measure, identify and compare this subject in educational and non-educational organizations. The present study therefore reviewed previous studies conducted on this subject with regard to three parts, i.e. skills, knowledge and attitude, and examined variables such as age, gender, marital status, position, academic degree, school and place of residence. Studies conducted to develop models for assessing ereadiness have identified some of the most suitable variables for assessing this concept; the review of these studies reveals a degree of overlap between the variables proposed in the present study and those proposed in more well-known-earning readiness models. Machado conducted a focus group interview study and developed a framework for e-learning acceptance at three levels: The organization (capacities, policies and strategies, motivation, education, performance assessment, infrastructure and access to facilities), the instructor (attitude, resistance in technology acceptance, technical knowledge and skills) and the learners (attitude, resistance and acceptance, technical knowledge and computer and language skills) (Machado, 2007). Finally, Williams et al. examined e-readiness assessment frameworks in a systematic review of 174 articles on e-readiness and found that most of these articles have used similar theoretical frameworks for assessing the readiness of organizations to accept the e-learning technology-frameworks that comprised of variables such as performance expectations, social influences, facilities, behavioral concepts, willingness to use, experience of working with technology, age and gender (Williams, Rana, \& Dwivedi, 2015).

As a conclusion based on the research question which was, development, validation and implementation of the Academics' E-Readiness questionnaire (ARQ) at Shiraz University of Medical Sciences to propose for other medical universities the present study, firstly, developed and validated the proposed questionnaire and secondly, the implementation of the questionnaire, revealed significant relationships between the discussed variables in e-learning; as skills and attitude were related significantly to position, academic degree, school, place of residence.

ACKNOWLEDGEMENTS: The authors thank the Vice-chancellor of Shiraz University of Medical Sciences for supporting this research (Code: 88-4618). This manuscript is based on the research proposal by authors. The authors also thank the Clinical Research Development Center of Shiraz University of Medical Sciences for the statistical analysis. 


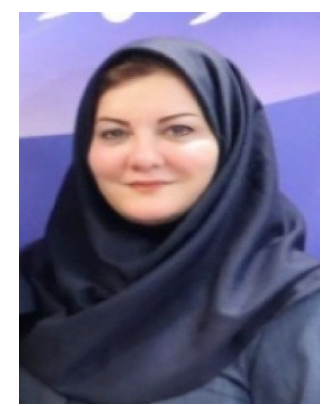

Dr. Nahid ZARIFSANAIEY is an Associate professor of the department of Elearning, Virtual School, and Comprehensive Center of Excellence for e-Learning in Medical Sciences. She lectures on e-learning concepts and principles, designs multimedia courses and supporting systems, conducts student evaluation, quality control and assurance in e-learning subjects for graduate and post graduate students of learning and medical education. She is also a director of many Master and doctoral theses and has written several articles in international journals. Dr. Zarifsanaiey is interested in designing Ubiquitous and mobile environments in medical sciences, collaborative learning, patient education, simulation, and virtual patients.

\section{Dr. Nahid ZARIFSANAIEY}

Department of E-learning, Virtual School, Comprehensive Center of Excellence for e-Learning in Medical Sciences

Address: Shiraz University of Medical Sciences, Postal Code: 7153675541, Shiraz, Iran

Phone: +989177105042

E-mail: nzarifsanaee@gmail.com

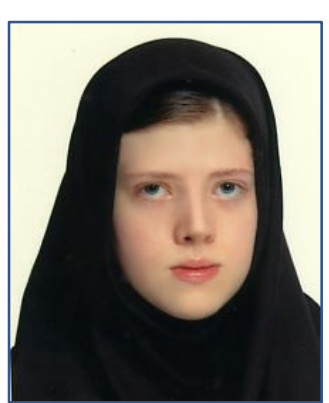

Seyede Shima KARANJAM is a Ph.D. student of Business policy and Strategic Management at faculty of Management ,University of Tehran. Shima Karanjam began her doctoral studies in 2017 and she gained her Master degree in Human Resources Management at Shiraz University at September 2016. Her academic interest areas are Strategic Management, Philosophy and theorizing in management, Intellectual Capital Management, metaphorical Modeling in Management, Organizational Culture, management philosophy and paradigms, E learning Modeling, Organizational Behavior. she has over than 7 journal articles accepted and published in domestic and international indexes, 4 domestic Managerial and Strategic Reaserch projects at Educational, Research and Health Organizations.

Seyede Shima Karanjam

Faculty of management

Address: faculty of Management, University of Tehran, Tehran, Iran.

Phone: +98 9171892140,

E-mail: sh.karanjam@ut.ac.ir

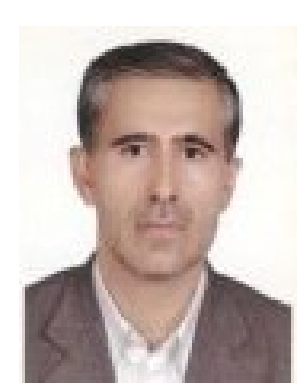

Dr. Mohammad Hossein KAVEH is Associate Professor of Health Education \& Promotion at School of Public Health in Shiraz University of Medical Sciences, Iran. Dr. Kaveh gained his Ph.D. in Health Education \& Promotion at August 2003. His academic interest areas are learning analytics, open and distance learning, education futures, e-learning, planning and evaluating (health) education programs. He has over than 80 journal articles published in international indexes, 4 national book chapters and other national and international articles, papers submitted to international meetings.

Dr. Mohammad Hossein KAVEH

Department of Health Promotion, Faculty of Public Health, Address: Shiraz University of Medical Sciences, Postal Code: 7153675541, Shiraz, Iran

Phone: +987137256216

E-mail: kaveh@sums.ac.ir 
Dr. Manoosh MEHRABI is Assistant Professor of e-Learning Planning in Medical Sciences Department, Virtual School as Center of Excellence for e-Learning in Medical Sciences. Dr. Mehrabi gained his Ph.D. in Distance Educational Planning at December, 2012. Her academic interest areas are e-Content Development, Instructional Design, e-Learning, Distance Education, e-learning Tools \& Technologies, Teaching Methods. She has over than 10 journal articles published in international indexes, and other national and international articles, papers submitted to international meetings.

Dr. Manoosh MEHRABI

Department of E-learning, Virtual School, Comprehensive Center of Excellence for e-Learning in Medical Sciences

Address: Shiraz University of Medical Sciences, Postal Code: 7153675541, Shiraz, Iran

Phone: +9832361618

E-mail: mehrabi.manoosh@gmail.com

\section{REFERENCES}

Aboelmaged, M. G. (2014). Predicting e-readiness at firm-level: An analysis of technological, organizational and environmental (TOE) effects on e-maintenance readiness in manufacturing firms. International Journal of Information Management, 34(5), 639-651.

Ahmed, H. M. S. (2010). Hybrid E-Learning acceptance model: Learner perceptions. Decision Sciences Journal of Innovative Education, 8(2), 313-346.

Akaslan, D., \& Law, E. L. (2011). Measuring teachers' readiness for 6 -learning in higher education institutions associated with the subject of electricity in Turkey. Paper presented at the Global Engineering Education Conference (EDUCON), 2011 IEEE.

Aslani, E., Babakhani, M., Karami, A. A., \& Amirteimori, M. H. (2016). Evaluation of the readiness for e-learning from the viewpoints of the students and professors of Allameh Tabataba'i University. Interdisciplinary Journal of Virtual Learning in Medical Sciences (IJVLMS), 7(1), 12-21.

Aydın, C. H., \& Tasci, D. (2005). Measuring readiness for e-learning: reflections from an emerging country. Educational Technology and Society, 8(4), 244-257.

Darab, B., \& Montazer, G. A. (2011). An eclectic model for assessing e-learning readiness in the Iranian universities. Computers \& Education, 56(3), 900-910.

Emami, H. (2010). Key success factors in E-learning and preparation exact departments in medical education. Journal of Hospital, 8(3), 57-67.

Hourali, M., Fathian, M., Montazeri, A., \& Hourali, M. (2013). A model for e-readiness assessment of Iranian small and medium enterprises. Journal of Algorithms and Computation, 41(7), 969-985.

Karanjam, S. S., Karanjam, S., \& Sanaiey, N. Z. (2017). Designing a Comprehensive Organizational ELearning Model Using the Meta-Synthesis Method. Interdisciplinary Journal of Virtual Learning in Medical Sciences, 8(3).

Keramati, A., Afshari-Mofrad, M., \& Kamrani, A. (2011). The role of readiness factors in E-learning outcomes: An empirical study. Computers \& Education, 57(3), 1919-1929. 
Machado, C. (2007). Developing an e-readiness model for higher education institutions: results of a focus group study. British journal of educational technology, 38(1), 72-82.

Mutula, S. M., \& van Brakel, P. (2006). E-readiness of SMEs in the ICT sector in Botswana with respect to information access. The electronic library, 24(3), 402-417.

Saeid, N., \& Mehrabi, M. (2013). Effectiveness of Teaching Cognitive and Metacognitive Strategies on Strengthen their, Student Self-Directed Learning Readiness and Self Efficacy. Interdisciplinary Journal of Virtual Learning in Medical Sciences (IJVLMS), 4(3), 29-39.

Tarhini, A., Hone, K., \& Liu, X. (2014). The effects of individual differences on e-learning users' behaviour in developing countries: A structural equation model. Computers in Human Behavior, 41, 153-163.

Vahidi, H. (2013). Designing a Domestic E-readiness Assessment Model for the Deployment of Mobile Learning. Interdisciplinary Journal of Virtual Learning in Medical Sciences (IJVLMS), 4(1), 1-10.

Williams, M. D., Rana, N. P., \& Dwivedi, Y. K. (2015). The unified theory of acceptance and use of technology (UTAUT): a literature review. Journal of Enterprise Information Management, 28(3), 443-488.

Zarshenas, L., Keshavarz, T., Momennasab, M., \& Zarifsanaiey, N. (2017). Interactive Multimedia Training in Osteoporosis Prevention of Female High School Students: An Interventional Study. Acta Medica Iranica, 55(8), 514. 